\title{
Satellite Monitoring of the Evolution of a Coccolithophorid Bloom in the Southern Benguela Upwelling System
}

\author{
Scarla J. Weeks \\ University of Cape Town • Rondebosch, South Africa \\ Grant C. Pitcher \\ Marine and Coastal Management - Rogge Bay, South Africa \\ Stewart Bernard \\ University of Cape Town • Rondebosch, South Africa
}

Upwelling systems are thought to be characterized by the dominance of chain-forming diatoms, and the large fisheries typical of coastal upwelling systems are considered to be based on the classical food chain of "diatoms - copepods - fish" (Cushing, 1989). Little consideration has been given to the contribution of coccolithophorids to the phytoplankton communities in upwelling systems. The coccolithophorids belong to the Prymnesiophyceae and are able to synthesize external calcium carbonate platelets, or coccoliths, which cover the outer surface of the cell. Coccolithophorids are globally cosmopolitan (Brown and Yoder, 1994) and known to form near mono-specific blooms that can extend over large areas of the ocean surface (Holligan et al., 1983, 1993). Such blooms provide a milky turquoise colour to the ocean, owing to the scattering properties of the coccoliths (Balch et al., 1996a). These small inorganic platelets are extremely effective scatterers, particularly when detached from the host cells. It is largely the influence of high concentrations of these detached coccoliths that cause coccolithophorid blooms to differ optically from other blooms of noncalcifying marine phytoplankton (Ackleson et al., 1994; Balch et al., 1996a) due to their high effective refractive index and typically small size (Voss et al., 1998).

An increase in backscattering relative to absorption, the two processes primarily responsible for the quality of light returned to the sea surface, induced by the presence of coccoliths, is responsible for the increased reflectance values associated with coccolithophorid blooms. Surface irradiance reflectance values (the ratio of upwelling to incoming irradiance measured above the sea surface) of over $20 \%$ have been reported (Groom and Holligan, 1987). These high reflectance values are visible from satellite, allowing coccolithophore blooms to be distinguished. The evolution of such blooms can therefore be analyzed using satellite-derived pseudo-true color imagery as an alternative to the traditional phytoplankton biomass proxy of chlorophyll a concentration. Here we document the evolution of a coccolithophorid bloom in the southern Benguela along the west coast of South Africa during the autumn of 2003, using satellite ocean color and sea surface temperature imagery.

\section{Satellite Imagery}

The coccolithophore signal was initially identified in 24-bit, pseudo-true color composites generated from Orbview-2 Sea-viewing Wide Field-of-view Sensor (SeaWiFS) calibrated and Rayleigh-corrected radiances at $670 \mathrm{~nm}, 555 \mathrm{~nm}$, and $412 \mathrm{~nm}$ (bands 6, 5 and 1, respectively) ${ }^{1}$. The one-kilometer resolution SeaWiFS data were acquired and processed locally and the signal thus monitored throughout the event. Pseudotrue color imagery generated from the ModerateResolution Imaging Spectroradiometer (MODIS) onboard NASA Terra and Aqua satellites using bands 1,4 and 3 (at $645 \mathrm{~nm}, 555 \mathrm{~nm}$ and $469 \mathrm{~nm}$, respectively), was additionally acquired ${ }^{2}$. With a resolution of $250 \mathrm{~m}$ (band 1) and $500 \mathrm{~m}$ (bands 4 and 3), the higher resolution allowed for a more detailed analysis of the event.

Daytime NOAA AVHRR (Advanced Very High

${ }^{1}$ The code used to produce the quasi-true color images was provided by Norman Kuring and the SeaWiFS Project.

${ }^{2}$ Provided by the Modis Rapid Response Team 
Resolution, $1 \mathrm{~km}$ ) sea surface temperature images generated locally using the standard McClain et al., (1985) algorithm provided information on the physical environment important in determining the evolution of the bloom. Chlorophyll $a$ concentration, representing phytoplankton biomass, was determined using the SeaWiFS Data Analysis System (SeaDAS) and the OC4v4 algorithm (O'Reilly et al., 2000). This fourth order polynomial equation, uses a maximum band ratio such that chlorophyll $a$ concentration (Ca):

$$
\begin{gathered}
\mathrm{C}_{\mathrm{a}}=10.0 \exp \left(0.366-3.067 \mathrm{R}_{4 \mathrm{~S}}+\right. \\
\left.1.930 \mathrm{R}_{4 \mathrm{~S}}{ }^{2}+0.649 \mathrm{R}_{4 \mathrm{~S}}{ }^{3}-1.532 \mathrm{R}_{4 \mathrm{~S}}{ }^{4}\right),
\end{gathered}
$$

where the band ratio, $\mathrm{R}_{4 \mathrm{~S}}=\log _{10}$ $\left(\mathrm{R}^{443}{ }_{555}>\mathrm{R}^{490}{ }_{555}>\mathrm{R}_{555}^{510}\right)$, and in $\mathrm{R}_{4 \mathrm{~S}}$, the numerical part denotes the number of bands used and $S$, the SeaWiFS sensor. The argument of the logarithm represents the maximum of the three values, each being a ratio of SeaWiFS normalized water-leaving radiances (a measure of the satellite signal after atmospheric correction, representing light leaving the sea normalized to incoming extraterrestrial values) at the specified wavelengths.

\section{Bloom Evolution}

A sequence of satellite images from the 26 March to 5 May 2003 documents the evolution of the bloom. Dominated by Syrachosphaera pulchra, the bloom was confined to the region between the Namaqua and Cape Columbine upwelling cells where a broadening of the shelf favors stratification of the water column, conducive to the development of flagellate dominated blooms. This region is thought to be characterized by retentive, near-surface circulation patterns dominated by a cyclonic gyre north of St. Helena Bay (Holden 1985, Probyn et al. 2000), and is an area particularly susceptible to red tide formation and its negative impacts (Pitcher and Calder 2000).

The bloom was first observed towards the end of March (Figure 1a) to the north of St. Helena Bay following a period of moderate upwelling. The bloom was associated with warm water $\left(16^{\circ} \mathrm{C}\right)$ on the seaward edge of the upwelling front demarcating a narrow band of upwelling inshore (Figure 1e). Under diminished upwelling activity and increased thermal stratification (Figure 1f) the bloom intensified (Figure $1 b)$ and was advected into St. Helena Bay during the first few days of April (Figure 1c). Under these conditions the frontal system and associated bloom are considered to move shoreward, and the development of an inshore counter current results in the southward progression of the bloom. Although the resumption of upwelling conditions displaced the bloom from the coast during the second week of April (Figure 1d and h), the bloom remained in St. Helena Bay and extended a distance of $220 \mathrm{~km}$ to the north. Relaxation of upwelling conditions during mid-April once again favored southward advection of the bloom and on the 19th April (Figure 2a and e) the bloom was observed rounding Cape Columbine. This southward advection of blooms is thought to be associated with barotropic flow inshore generated by coastal-trapped waves over the southern Namaqua shelf (Lamberth and Nelson 1987; Pitcher et al., 1998; Pitcher et al., submitted). The surface manifestation of this current is not continuous but usually appears as a flood event (Probyn et al., 2000). Advection of the bloom around Cape Columbine ceased with the resumption of upwelling towards the end of April (Figure 2b and f). Termination of the bloom was associated with quiescent conditions and extensive warming of St Helena Bay (Figure 2c, g, d and h), 41 days after the bloom was first observed.

\section{In Situ Measurements}

In situ measurements were made off Lambert's Bay on 15 April 2003 (Figure $3 \mathrm{a}$ and b: Station 1). The coccolithophorid Syrachosphaera pulchra and a mixed assemblage of dinoflagellates dominated the phytoplankton assemblage. The coccolithophorid concentration approximat-

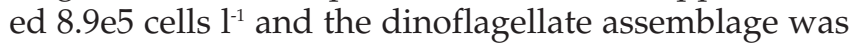
dominated by Prorocentrum triestinum and Scripsiella trochoidea. Surface spectroradiometric measurements were also made allowing assessment of the SeaWiFS sensor to accurately determine normalized water-leaving radiance $(\mathrm{nLw})$ under bloom conditions. A Satlantic HyperTSRB (Satlantic Inc., Halifax, Canada) was used to obtain near surface upwelling radiance (upwardly directed light flux per solid angle just beneath the sea surface) and above surface irradiance. Subsurface radiance data were propagated to the surface using diffuse attenuation values (a measure of the attenuation of naturally occurring upward light flux), as determined by the Austin and Petzold (1981) and Morel (1988) models. Normalized water-leaving radiance values were then calculated using the protocols of Mueller et al. (2003). Normalized water-leaving radiance values corresponding to Station 1 were also extracted from SeaWiFS overpass data on the 15 April 2003 (Figure 4). The match between in situ and satellite derived $\mathrm{nLw}$ values is extremely good, with the SeaWiFS values within $5 \%$ of surface measured values at all wavelengths.

Further in situ measurements were made in St. Helena Bay at Stations 2, 3, 4 and 5 on 24 April 2003 (Figure $3 c$ and d). Stations 2 and 3 were both dominated by the coccolithophorid Syrachosphaera pulchra at concentrations of $9.1 \mathrm{e} 5$ and $6.4 \mathrm{e} 5$ cells $\mathrm{l}^{-1}$ respectively, 

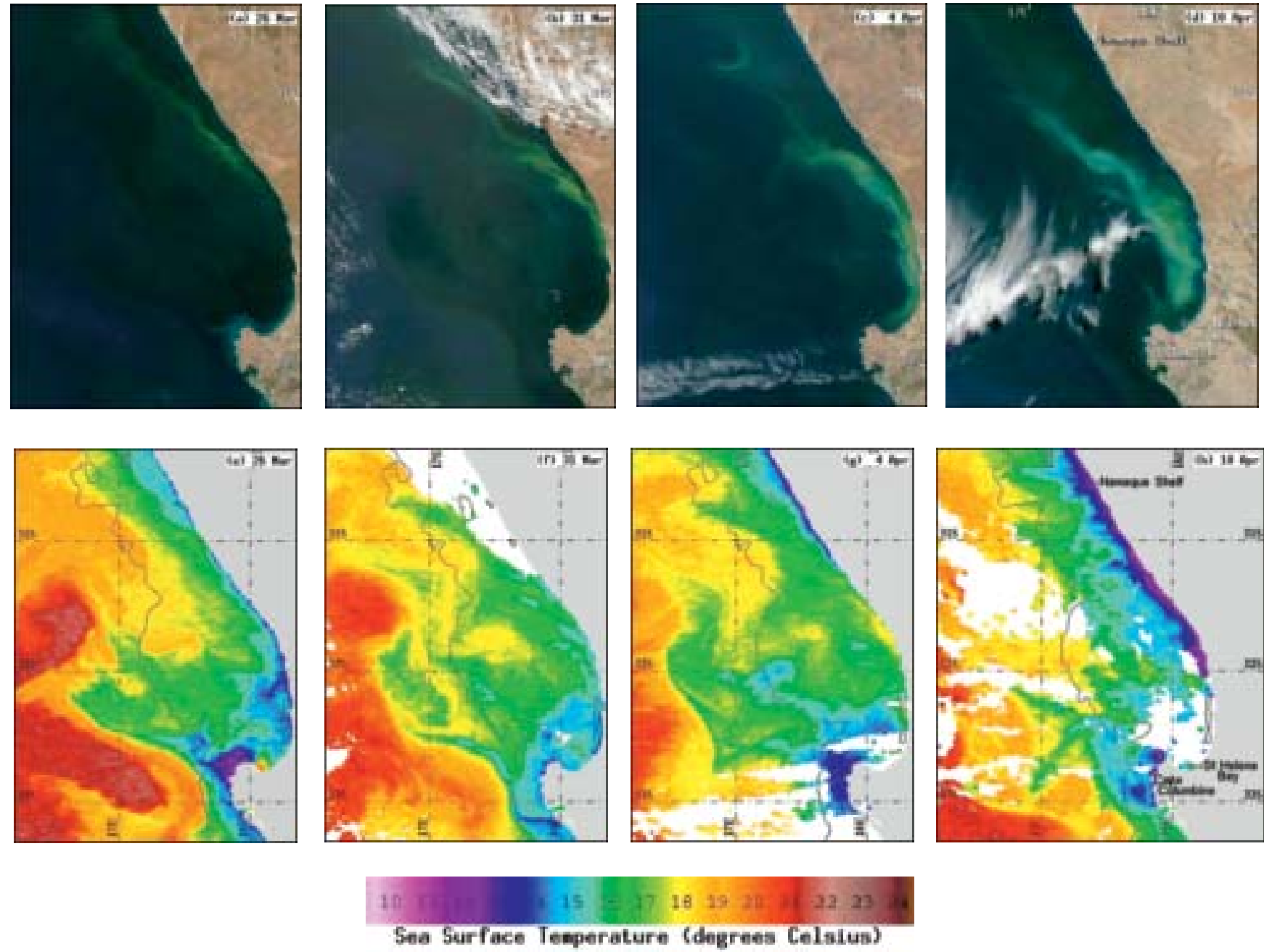

Figure 1. Modis pseudo true color (TC) and NOAA AVHRR false color SST images for the region lon $16.2^{\circ} \mathrm{E}-18.7^{\circ} \mathrm{E} ;$ lat $30.3^{\circ} \mathrm{S}-33.3^{\circ} \mathrm{S}$ during the period March-April 2003. (a) TC 26 March; (b) TC 31 March; (c) TC 4 April; (d) TC 10 April; (e) SST 26 March; (f) SST 31 March; (g) SST 4 April; (h) SST 10 April. The area of milky turquoise coloration in panels (a)-(d) indicates high concentrations of the coccolithophorid Syrachosphaera pulchra in surface waters. White patches represent cloud. The black contour represents the $200 \mathrm{~m}$ isobath.

while dinoflagellate concentrations approximated 4.8e4 and 6.1e4 cells 1 ${ }^{-1}$ (Table 1). Dinoflagellates (2.5e5 cells $1^{-1}$ ) dominated the phytoplankton assemblage at Station 4 with Ceratium lineatum the most common species. The concentration of Syrachosphaera pulchra was only $6.1 \mathrm{e} 4$ cells $^{-1}$ (Table 1 ). At Station 5 diatoms dominated the assemblage with Skeletonema costatum the most abundant species $\left(2.8 \mathrm{e} 5\right.$ cells $\left.\mathrm{l}^{-1}\right)$. Normalized water-leaving radiance values corresponding to Stations 1-5 were also extracted from SeaWiFS overpass data on the 24 April 2003 (Figure 4).

A comparison of water-leaving radiance values (Figure 4) and phytoplankton assemblage data (Table 1) confirm that stations with high concentrations of $S$. pulchra (Stations 1, 2 and 3) all show elevated nLw values, associated with the presence of highly backscattering calcite particles in surface waters. The varying ratio of detached coccoliths to coccolithophorids may be responsible for the imprecise relationship between radiance values and the concentration of S. pulchra because detached coccoliths are more effective backscatterers than the whole plated cells, and are thus the principal source of highly elevated reflectance values (Balch et al., 1996a; Voss et al., 1998). Detachment of coccoliths is typically a function of bloom age; declining or stationary phase blooms have a higher ratio of detached coccoliths (Balch et al., 1993; 1996a). The variable presence of a mixed dinoflagellate community (Table 1), on occasion reaching concentrations of

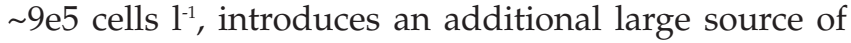
absorbing material to the gross optical signal. Thus whilst the S. pulchra cell counts demonstrate that the elevated reflectance values can be used as a gross coccolithophorid bloom tracer, the complex admixture of 

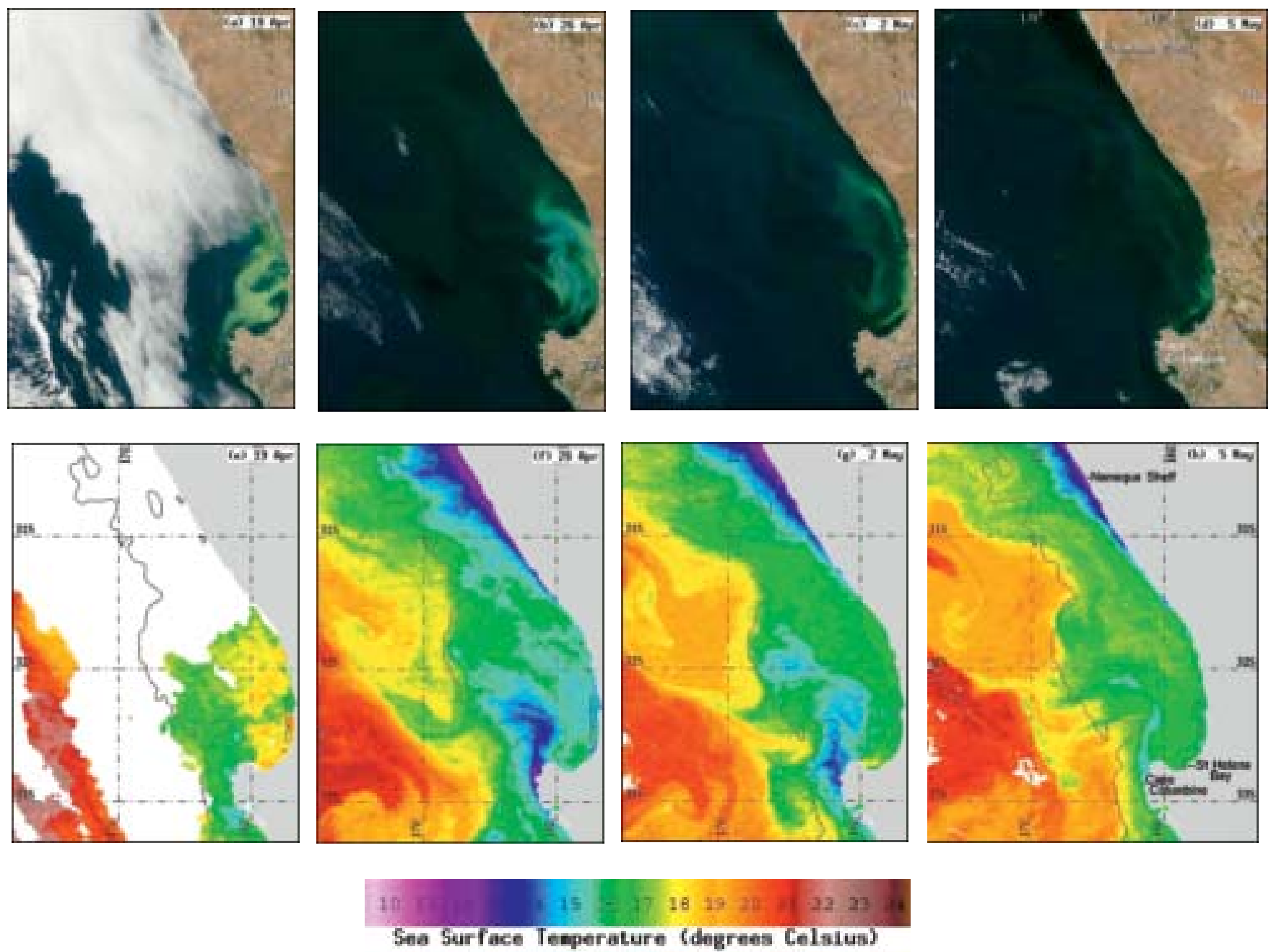

Figure 2. Modis pseudo true colour (TC) and NOAA AVHRR false color SST images for the region lon $16.2^{\circ} \mathrm{E}-18.7^{\circ} \mathrm{E}$; lat

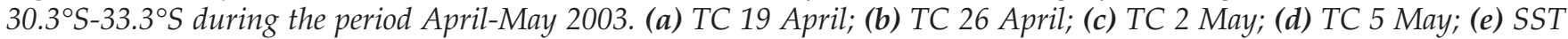
19 April; ( $f$ ) SST 26 April; (g) SST 2 May; (h) SST 5 May. The area of milky turquoise coloration in panels (a)-(d) indicates high concentrations of the coccolithophorid Syrachosphaera pulchra in surface waters. White patches represent cloud. The black contour represents the $200 \mathrm{~m}$ isobath.

unquantified absorbing and backscattering material precludes a more detailed analysis of the bloom's optical signature.

Furthermore, the high reflectivity of coccolithophorids and associated coccoliths at the sea surface interferes with the SeaWiFS chlorophyll estimation. Not only are the radiances used in the bio-optical algorithm affected by high reflectivity, but the radiances used in the atmospheric correction process are also likely to be adversely affected by the high reflectance. Since the bio-optical algorithm uses band-ratios with the denominator, $555 \mathrm{~nm}$, assumed to be relatively stable, the presence of coccolithophorids or coccoliths at any one location, producing a significant contribution at $555 \mathrm{~nm}$, will tend to yield erronenous estimates of chlorophyll a. The effect on SeaWiFS normalised water-leaving radiances of a mixed coccolithophorid/dinoflagellate algal community, comprising both coccoliths and absorbing material, is apparent in the reflectance spectra shown in Figure 4.

In processing of SeaWiFS data, numerous thresholds are determined and data may be flagged for a specific condition. The SeaDAS "coccolithophore flag" is determined by several boundary conditions based on thresholds for normalized water-leaving radiances (nLw) at $443 \mathrm{~nm}$ and $555 \mathrm{~nm}$, the aerosol radiance at $670 \mathrm{~nm}$, and specific ratios of $\mathrm{nLw} \_443 / \mathrm{nLw}$ 555, nLw_510/nLw_555, and nLw_443/nLw_510 (Brown, 1995). At locations where the reflectance signal is intense, pixels are flagged as coccolithophore dominant (not shown), as the SeaWiFS chlorophyll algorithm is unable to accurately retrieve chlorophyll 

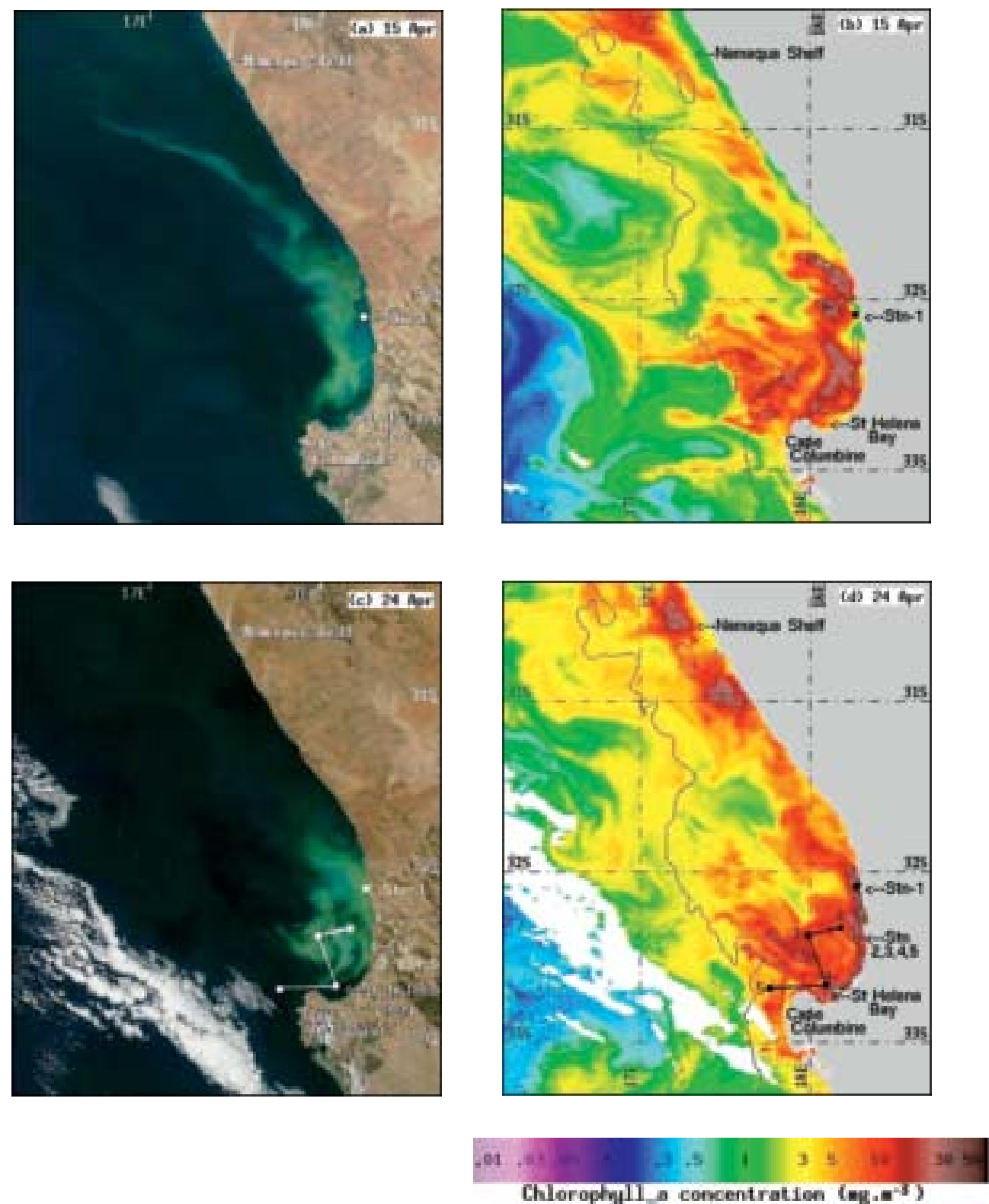

Figure 3. Modis pseudo true color (TC) and SeaWiFS false color chlorophyll a (CHL) images for the region lon $16.2^{\circ} \mathrm{E}-18.7^{\circ} \mathrm{E}$; lat $30.3^{\circ} \mathrm{S}-33.3^{\circ} \mathrm{S}$ on 15 and 24 April 2003. (a) TC 15 April; (b) CHL 15 April; (c) TC 24 April; (d) CHL 24 April. Locations of in situ sampling, Stations (1) - (5), are shown. The area of milky turquoise coloration in panels (a) and (c) indicates high concentrations of the coccolithophorid Syrachosphaera pulchra in surface waters. White patches represent cloud. The black contour represents the $200 \mathrm{~m}$ isobath.

values due to the high reflectivity and scattering. Examination of the satellite-derived individual normalized water-leaving radiances revealed high values at these locations, with values of nLw 490nm and nLw $510 \mathrm{~nm}$ approximately equal to or even exceeding that of nLw 555nm; hence the result would be a depressed estimate of chlorophyll. Satellite-derived chlorophyll values for stations with high concentrations of $S$. pulchra (Stations 1, 2 and 3) are on average 52\% lower than chlorophyll concentrations measured in situ
(Table 1). Generally, the OC4V4 bio-optical algorithm becomes untrustworthy in any "Case 2" waters, where constituents other than chlorophyll contribute significantly to the in-water light field (O'Reilly et al., 2000).

\section{Conclusion}

We have documented here a recent, unusual coccolithophorid bloom in southern Benguela waters, the first such extensive bloom monitored by satellite in this upwelling region. The bloom is also of the first 


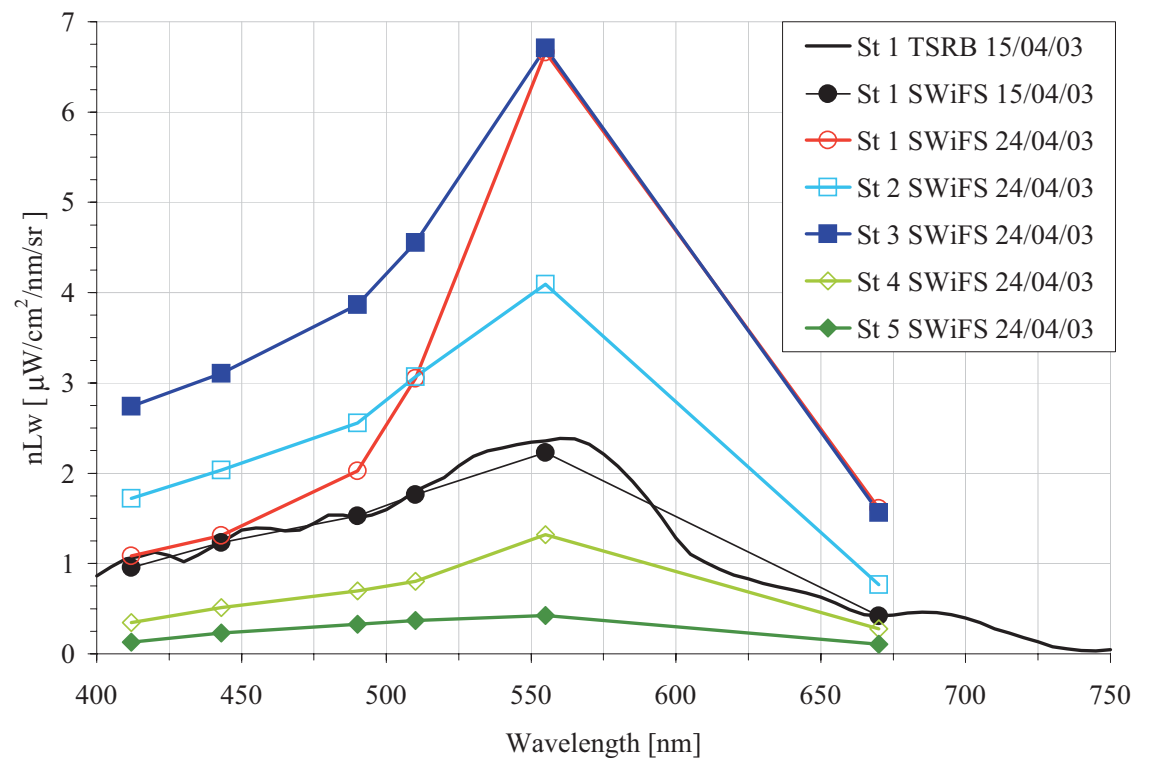

Figure 4. SeaWiFS and in-situ measurements of normalized water-leaving radiance for the five sampling stations. The close match between satellite and in-situ radiance values, and the elevated radiance values associated with high concentrations of S. pulchra can be observed.

\section{Table 1}

In-situ measurements of chlorophyll a $\left(\mathrm{mg} \mathrm{m}^{-3}\right)$, and cell counts for Syracosphaera pulchra, total dinoflagellates, and total diatoms (cells $1^{-1}$ ), for the five sampling stations.

\begin{tabular}{l|c|c|c|c|c|c} 
Station & Date & $\begin{array}{c}\text { OC4v4 } \\
\text { Chl a }\end{array}$ & $\begin{array}{c}\text { In-situ } \\
\text { Chl a }\end{array}$ & S.pulchra & Dinoflagellates & Diatoms \\
\hline St 1 & $4 / 15 / 2003$ & 5.6 & 26.9 & $8.9 \mathrm{E}+05$ & $9.0 \mathrm{E}+05$ & 0 \\
\hline St 1 & $4 / 24 / 2003$ & 43.9 & - & - & - & - \\
\hline St 2 & $4 / 24 / 2003$ & 6.8 & 9.7 & $9.1 \mathrm{E}+05$ & $4.8 \mathrm{E}+04$ & 0 \\
\hline St 3 & $4 / 24 / 2003$ & 9.7 & 18.3 & $6.4 \mathrm{E}+05$ & $6.1 \mathrm{E}+04$ & 0 \\
\hline St 4 & $4 / 24 / 2003$ & 14.8 & 18.7 & $6.1 \mathrm{E}+04$ & $2.5 \mathrm{E}+05$ & 0 \\
\hline St 5 & $4 / 24 / 2003$ & 4.0 & 6.1 & 0 & $2.2 \mathrm{E}+04$ & $2.8 \mathrm{E}+05$ \\
\hline
\end{tabular}

monitored by MODIS satellite ocean color, the $250 \mathrm{~m}-$ $500 \mathrm{~m}$ resolution allowing detailed analysis not possible previously.

Eleven algal classes are represented in the phytoplankton among which diatoms, dinoflagellates and coccolithophorids are pre-eminent. The above observations are consistent with previous observations of diatoms dominating in colder, nutrient-rich waters, coccolithophorids in warmer oligotrophic waters, and dinoflagellates somewhat intermediate in general environmental preference (Smayda 1980). Although coccolithophorids are typically characteristic of oligotrophic waters, species such as Emiliania huxleyi exhibit unexpectedly good growth in enriched coastal waters at suitable temperatures. As a result E. huxleyi and Gephyrocapsa oceanica are notorious for forming massive blooms, but blooms of other coccolithophorids including species of the genus Syrachosphaera are rarely reported. This paper demonstrates the detection and monitoring from space of such an unusual bloom in southern Benguela waters, dominated by a species not previously reported to form such intense concentrations.

\section{Acknowledgements}

We wish to thank the Modis Rapid Response Team for processing and making available the MODIS quasitrue color imagery, Andre du Randt and Desiree Calder for the collection and processing of samples, Christo 
Whittle for assistance in image processing. We gratefully acknowledge the French Ministry of Foreign Affairs (FSP) for its financial support. We also wish to take this opportunity to express special thanks to Dr. Gene Feldman and the SeaWiFS Project, NASA, for continuing interest and collaboration in the application of SeaWiFS and ocean colour data to southern Africa regional waters.

\section{References}

Ackleson, S.G., W.M. Balch, and P.M. Holligan, 1994: Response of water-leaving radiance to particulate calcite and chlorophyll a concentrations: A model for Gulf of Maine coccolithophore blooms. J Geophys Res, 99: 7483-7499.

Austin, R.W., and T.J. Petzold, 1981: The determination of the diffuse attenuation coefficient of sea water using the coastal zone color scanner. Pp. 239-255 in Oceanography from Space, J.F R. Gower, ed.

Balch, W.M., K.A. Kilpatrick, and P.M. Holligan, 1993: Coccolith formation and detachment by Emiliania huxleyi (Prymnesiophyceae). J. Phycol., 29: 566-575

Balch, W.M., K.A. Kilpatrick, P.M. Holligan, D.S. Harbour, and E. Fernandez, 1996a: The 1991 coccolithophore bloom in the central North Atlantic. 2. Relating optics to coccolith concentration. Limnol. Oceanogr., 41, 1684-1696.

Brown, C.W., 1995: Classification of coccolithophore blooms in ocean color imagery." In: Mclain, C.R., W.E. Esaias, M. Darzi, F.S. Patt, R.H. Evans, J.W. Brown, K.R. Arrigo, C.W. Brown, R.A. Barnes, and L. Kumar, 1995: Case Studies for SeaWifs calibration and Validation, Part 4. NASA Tech. Memo. 104566, Vol. 28, S.B. Hooker, E.R. Firestone, and J.G. Acker, Eds., NASA Goddard Space Flight Center, Greenbelt, Maryland, 13-19.

Brown, C.W. and J.A. Yoder, 1994: Coccolithophorid blooms in the global ocean. J. Geophys. Res., 99(C): 7467-7482.

Cushing, D.H., 1989: A difference in structure between ecosystems in strongly stratified waters and those that are only weakly stratified. J. Plankt. Res., 11(1): $1-13$.

Groom, S.B., and P. M. Holligan, 1987: Remote sensing of coccolithophore blooms. Adv. Space Res., 7, 73-78.

Holden, C.J., 1985: Currents in St Helena Bay inferred from radio-tracked drifters. Pp. 97-109 in The South African Ocean Colour and Upwelling Experiment., L.V. Shannon, ed. Cape Town; Sea Fisheries Research Institute.

Holligan, P.M., M. Viollier, D.S. Harbour, P. Camus, and M. Champagne-Philippe, 1983: Satellite and ship studies of coccolithophore production along a continental shelf edge. Nature, 304: 339-342.

Holligan, P.M., E. Fernandez, J. Aiken, W.M. Balch, P. Boyd, P.H. Burkhill, M. Finch, S.B. Groom, G. Malin, K. Muller, D.A. Purdie, C. Robinson, C.C. Trees, S.M. Turner, and P. van der Wal, 1993: A bio- geochemical study of the coccolithophore Emiliania huxleyi in the north Atlantic. Global Biogeochem. Cycles, 7: 879-900.

Lamberth, R., and G. Nelson, 1987: Field and analytical drogue studies applicable to the St Helena Bay area off South Africa's west coast. In: The Benguela and Comparable Ecosystems, A.I.L. Payne, J.A. Gulland, and K.H. Brink, eds. S. Afr. J. Mar. Sci., 5: 163-169.

McClain, E.P., W.G. Pichel, and C.C. Walton, 1985: Comparative performance of AVHRR-based multichannel sea surface temperatures. J. Geophys. Res., 90, 11587-11601.

Morel, A., 1988: Optical modeling of the upper ocean in relation to its biogenous matter content (Case I waters). J. Geophys. Res., 93(C9), 10749-10768.

Mueller, J.M. et. al., 2003: Ocean Optics Protocols For Satellite Ocean Color SensorValidation, Revision 4, Volume III: Radiometric Measurements and Data Analysis Protocols, NASA/TM-2003-21621/RevVol III.

O'Reilly, J.E., S. Maritorena, D. Siegel, M.C. O’Brien, D. Toole, B.G. Mitchell, M. Kahru, F.P Chavez., P. Strutton, G. Cota, S.B. Hooker, C.R. McClain, K.L. Carder, F. Muller-Karger, L. Harding, A. Magnuson, D. Phinney, G.F. Moore, J. Aiken, K.R. Arrigo, R. Letelier, and M. Culver, 2000: Ocean color chlorophyll $a$ algorithms for SeaWiFS, OC2, and OC4: Version 4. In: Hooker, S.B., Firestone, E.R., (Eds.), SeaWiFS Postlaunch Calibration and Validation Analyses, Part 3. SeaWiFS Postlaunch Technical Report Series, 11, NASA, Goddard Space Flight Center, Greenbelt, Maryland, pp. 9-23.

Pitcher, G.C., A.J. Boyd, D.A. Horstman, and B.A. Mitchell-Innes, 1998: Subsurface dinoflagellate populations, frontal blooms and the formation of red tides in the southern Benguela upwelling system. Mar. Ecol. Prog. Ser., 172: 253-264.

Pitcher, G.C., and D. Calder, 2000: Harmful algal blooms of the southern Benguela current: a review and appraisal of monitoring from 1989 to 1997. S. Afr. J. Mar. Sci., 22: 255-271.

Pitcher, G., P. Monteiro, and A. Kemp, submitted: The potential use of a hydrodynamic model in the prediction of harmful algal blooms in the southern Benguela.

Probyn, T.A., G.C. Pitcher, P.M.S. Monteiro, A.J. Boyd, and G. Nelson, 2000: Physical processes contributing to harmful algal blooms in Saldanha Bay. S. Afr. J. Mar. Sci., 22: 285-297.

Smayda, T.J., 1980: Phytoplankton species succession. In: The Physiological Ecology of Phytoplankton, I. Morris, ed, Blackwell Scientific Publications, Oxford, London.

Voss, K.J., W.M. Balch, and K.A. Kilpatrick, 1998: Scattering and attenuation properties of Emiliania huxleyi cells and their detached coccoliths. Limnol. Oceanogr., 43(5), 870-876. 